\title{
Quantitative sidedress nitrogen recommendations for potatoes based upon crop nutritional indices
}

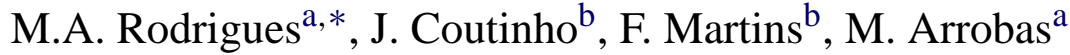 \\ ${ }^{a}$ CIMO, Escola Superior Agrária; 5301-855 Bragança, Portugal \\ ${ }^{\mathrm{b}}$ CECEA, University Trás-os-Montes e Alto Douro; 5001-911 Vila Real, Portugal
}

\begin{abstract}
The quantification of sidedress $\mathrm{N}$ rate from in-season information on crop $\mathrm{N}$ nutritional status is extremely important in order to use only the necessary amount of nutrient to achieve maximum yields without significant $\mathrm{N}$ losses from soil. During three consecutive years (1996, 1997 and 1998) field N fertilizer experiments with irrigated potato (Solanum tuberosum L., cv. Désirée) were conducted in Bragança (NE Portugal). Eight preplant treatments $(0,50,100,200$ and $300 \mathrm{~kg}$ urea-N/ha and poultry manure, farmyard manure and municipal solid waste in rates equivalent to $100 \mathrm{~kg}$ organic-N/ha) were arranged as main plots and five sidedress $\mathrm{N}$ rates $(0,25,50,100$ and $200 \mathrm{~kg}$ urea-N/ha) included as subplots. Petiole nitrate concentration, determined by a laboratory method ( $\mathrm{PNLab}, \mathrm{g} \mathrm{NO}_{3}-\mathrm{N} \mathrm{kg}^{-1}$, dry weight basis) and by the portable RQflex reflectometer (PNRQflex, $\mathrm{mg} \mathrm{NO}_{3} \mathrm{~kg}^{-1}$, from fresh tissues), and leaf $\mathrm{N}$ content (LeafN, $\mathrm{g} \mathrm{kg}^{-1}$, dry weight basis) were used as $\mathrm{N}$ nutritional indices. From the five sidedress $\mathrm{N}$ rates applied over each of the preplant treatments, critical sidedress $\mathrm{N}$ rates were estimated for several different crop $\mathrm{N}$ nutritional status. This was achieved by establishing exponential asymptotic curves between sidedress $\mathrm{N}$ rates and tuber yields and solving the equations for $95 \%$ of maximum tuber yield. In a second step, multiple regression equations were established between the estimated critical sidedress $\mathrm{N}$ rates (SNrate, $\mathrm{kg} \mathrm{N} / \mathrm{ha}$ ), as dependent variable, and each crop $\mathrm{N}$ nutritional indices (PNLab, PNRQflex or LeafN) and days after emergence (DAE). The equations obtained are:

SNrate $=182.7-4.146 \times$ PNLab $-1.87 \times$ DAE

SNrate $=161.0-0.013 \times$ PNRQflex $-1.34 \times$ DAE

SNrate $=562.2-8.416 \times$ LeafN $-3.59 \times$ DAE

These equations provide quantitative sidedress $\mathrm{N}$ rates for any level of crop $\mathrm{N}$ nutritional indices and sampling dates from 10 to 48 days after emergence.
\end{abstract}

Keywords: Solanum tuberosum; Crop N management; Decision support system; Plant analysis; Tissue testing

\section{Introduction}

Nitrogen is an important ecological factor. Its beneficial effects on crop growth are unquestionable, but if it 
is used in excess could lead to environmental contamination. Thus, the continuous improvement in fertiliser$\mathrm{N}$ recommendation programs is recognized worldwide. The main limitation in several $\mathrm{N}$ recommendation systems all over the world is the estimation of soil contribution to $\mathrm{N}$ nutrition of crops. In fact, reliable laboratory methods of soil analysis of universal acceptance and widespread use, providing information concerning soil $\mathrm{N}$ availability, are not yet developed. The problem arises from the difficulty in preventing the time and rate of mineralization of soil organic substrates (Dahnke and Johnson, 1990).

The uncertainty of fertiliser- $\mathrm{N}$ recommendations performed from soil analysis, before the start of the growing season, and the high efficiency of $\mathrm{N}$ used at sidedress (Westermann et al., 1988), have given importance to fertilizer-N recommendation systems that include information taken during the growing season. Thus, an acceptable strategy for $\mathrm{N}$ management seems to be the application at preplant of a part of $\mathrm{N}$ expected to be needed with the necessary adjustments as sidedress (Ojala et al., 1990; Porter and Sisson, 1991). Plant analysis or tissue testing allow assessing the crop nutritional status and, consequently, can be used to make in-season $\mathrm{N}$ fertilization adjustments in order to better balance $\mathrm{N}$ rates with crop needs.

The results of plant analysis are often interpreted by critical levels or sufficiency ranges previously defined for a given crop and for specific growing stages. The critical level identifies the crop nutritional status, above which there is no need to add more $\mathrm{N}$ and vice versa, but not informs about the amount of nutrient to apply. Lemaire and Gastal (1997) developed the nitrogen nutrition index (NNI), which could diagnose the intensity of $\mathrm{N}$ deficiency, as well as situations of luxury consumption. The NNI can be determined, for any crop and at any time, as the ratio between the actual plant $\mathrm{N} \%$ and the critical plant $\mathrm{N} \%$ corresponding to adequate crop growth. Nitrogen nutrition index values close to 1 identify situations of non-limiting $\mathrm{N}$ supply. Values greater than 1 indicate luxury consumption. The closer the value is to 0 , the greater the intensity of the $\mathrm{N}$ deficiency. However, in order to improve the accuracy of $\mathrm{N}$ recommendation programs, there is a pressing need for methodologies that truthfully quantify sidedress $\mathrm{N}$ rates from crop $\mathrm{N}$ nutritional indices or in-season soil tests. Attempts have already been made, namely by Baethgen and Alley (1989). Being one of the first and most interesting, this uses plant $\mathrm{N}$ concentration and crop $\mathrm{N}$ uptake as $\mathrm{N}$ nutritional indices in winter wheat. This, was followed by Singh (1993) in potato with petiole nitrate content and by Piekielek et al. (1995), Heckman et al. (1996) and most recently by Scharf (2001) on corn using, respectively, chlorophyll-SPAD readings, the pre-sidedress soil nitrate test and total $\mathrm{N}$ in whole plants and chlorophyll-SPAD readings. Their methodological basis consisted in establishing a relationship between the level of crop or soil $\mathrm{N}$ indicators and optimal sidedress $\mathrm{N}$ rates, for well-defined sampling dates.

The present study was conducted to quantify sidedress $\mathrm{N}$ rates for potato, based on two in-season crop $\mathrm{N}$ nutritional indices: the petiole nitrate concentration and leaf $\mathrm{N}$. The main improvement from previous work is that quantified sidedress $\mathrm{N}$ recommendations are presented not for particular sampling dates, but continuously for the first part of the growing season, between 10 and 48 days after emergence, while $\mathrm{N}$ use efficiency is high.

\section{Material and methods}

\subsection{Field experiments and laboratory analysis}

The survey was conducted between 1996 and 1998 in North-eastern potato-growing region of Portugal $\left(41^{\circ} \mathrm{N}\right.$ latitude and $6^{\circ} \mathrm{W}$ longitude), with a Mediterranean-type climate, hot and dry during the summer growing season. Irrigation is a must for successful potato growing. The soil is a eutric Cambisol, loamy textured, with $\mathrm{pH}\left(\mathrm{H}_{2} \mathrm{O}\right)$ of 6.5 and organic matter content of $15 \mathrm{~g} \mathrm{~kg}^{-1}$. Extractable $\mathrm{P}$ and $\mathrm{K}$ (ammonium lactate and acetic acid) ranged from 20 to $49 \mathrm{mg} \mathrm{kg}^{-1}$ and 84 to $149 \mathrm{mg} \mathrm{kg}^{-1}$, respectively. Previous crops were corn for silage in summer followed by triticale for silage, grown as winter inter-crop.

The field experiments were arranged as a split-plot design. The main plots consisted on the following eight preplant $\mathrm{N}$ treatments: 0, 50, 100, 200 and $300 \mathrm{~kg}$ urea$\mathrm{N} / \mathrm{ha}$ and poultry manure, farmyard manure and a municipal solid waste, applied in variable rates corresponding to $100 \mathrm{~kg}$ organic-N/ha. The main plots were split into subplots to include five sidedress $\mathrm{N}$ rates $(0$, 25, 50, 100 and $200 \mathrm{~kg}$ urea-N/ha). In 1996 and 1997 , the sidedress treatment of $200 \mathrm{~kg} \mathrm{~N} / \mathrm{ha}$ was not applied 
over the preplant treatments of 200 and $300 \mathrm{~kg} \mathrm{~N} / \mathrm{ha}$. The plots were laid out through the field in three blocks (three replicates). Each individual subplot consisted of $5 \mathrm{~m}$ long seven rows.

Phosphorus and potassium rates applied in 1996, 1997 and 1998 were, respectively, 26, 52 and $26 \mathrm{~kg}$ $\mathrm{P} / \mathrm{ha}$ and 75,125 and $66 \mathrm{~kg} \mathrm{~K} / \mathrm{ha}$. The urea of the preplant treatments, the organic amendments and $\mathrm{P}$ (superphosphate, $18 \% \mathrm{P}_{2} \mathrm{O}_{5}$ ) and $\mathrm{K}$ (potassium chloride, $60 \% \mathrm{~K}_{2} \mathrm{O}$ ) were broadcast and incorporated with preplanting tillage. Whole pre-sprouting tubers with sizes of 28-45 mm (1996) and 45-60 mm (1997 and 1998) were machine-planted on 28 May 1996, 28 May 1997 and 21 May 1998. Seed tubers were planted with a row spacing of $0.70 \mathrm{~m}$, and in-row spacing of $0.32 \mathrm{~m}$. Crop emergence (50\% of visible shoots) occurred 14 , 13 and 15 days after planting in 1996, 1997 and 1998, respectively. The urea of the sidedress $\mathrm{N}$ treatments was applied onto soil surface on 17 July 1996, 9 July 1997 and 24 June 1998 and incorporated with overhead irrigation water. Depth and interval irrigation application were based on FAO methods (Doorenbos and Pruit, 1977). Crop protection included weeds, late blight (Phytophthora infestans) and beetle (Leptinotarsa decemlineata) control. Detailed information of pesticides, rates and dates of application were previously reported (Rodrigues et al., 2001). The harvests occurred in late September after the full senescence of the plants. The fresh weights of marketable tubers (>35 mm) were recorded.

Fifty to sixty of the most recently matured leaves were taken from each plot. One-third of the full leaves were used for leaf $\mathrm{N}$ analysis. The remaining leaves were separated into blades and petioles for petiole nitrate analysis. The full leaves' samples and half of the petioles' samples were oven-dried $\left(65^{\circ} \mathrm{C}\right)$ and ground. The dry matter percentage of petioles was recorded. Leaf $\mathrm{N}$ was determined by Kjeldahl method, in a Kjeltec Auto 1030 Analyzer. From dried petiole subsamples, nitrate analysis were performed by adding $50 \mathrm{ml}$ of distilled water to $1.0 \mathrm{~g}$ of dry sample. The mixtures were shaken for $1 \mathrm{~h}$ and filtered. Nitrate-N concentrations were determined by the sulfanilamine method (Houba et al., 1989) and analysed in a segmented flow analyser. For quick testing, $5 \mathrm{~g}$ of the fresh petioles were macerated and boiled for $15 \mathrm{~min}$ in $100 \mathrm{ml}$ of distilled water. After cooling, final volumes of $300 \mathrm{ml}$ were lined up and nitrate concentrations in extracts determined by Reflectoquant test strips, read with the RQflex reflectometer (MERCK). During the 3 years survey, between 10 and 48 days after emergence, nine different sampling dates were chosen.

\subsection{Sidedress $N$ rates quantification as a function of crop $N$ nutritional status and sampling dates}

The sidedress $\mathrm{N}$ rates quantification as a function of crop $\mathrm{N}$ nutritional status and sampling dates involved two distinct steps. In the first one, we determined the critical sidedress $\mathrm{N}$ rates. By analogy with critical nutrient concentration in a given tissue, we define critical sidedress $\mathrm{N}$ rate as the point, above which the crop does not respond to more nutrient applied at sidedress. In practical terms, we determine the critical sidedress $\mathrm{N}$ rates after establishing the relationships between applied sidedress $\mathrm{N}$ rates and tuber yields and solving the equations for $95 \%$ of maximum tuber yield. This is an environmentally sound approach, since we accepted a yield reduction of 5\% as is usual in plant analysis studies. As was previously described, each of the preplant plots was sidedressed with five $\mathrm{N}$ doses, arranged as subplots. Thus, the response of the crop to $\mathrm{N}$ applied as sidedress allowed estimating critical sidedress $\mathrm{N}$ rates from very different crop $\mathrm{N}$ nutritional status, arising from the different urea- $\mathrm{N}$ and organic-N preplant treatments.

The relationships between the sidedress $\mathrm{N}$ rates and tuber yields were fitted by exponential asymptotic equations of the type of

$y=a-b \operatorname{EXP}(c x)$

where $y$ is tuber yield $(\mathrm{Mg} / \mathrm{ha}), x$ is applied sidedress $\mathrm{N}(\mathrm{kg} / \mathrm{ha})$ and $a$ and $b$ are coefficients estimated from experimental data. The exponential coefficient $c$ was predetermined to avoid non-linear regression analysis, which needs much computing time, as suggested by Neeteson and Wadman (1987). The exponential coefficient was estimated by:

$c=\frac{4 \ln (d)}{N_{\max }}$

where $d$ has values of $0.03,0.05,0.10,0.20,0.35,0.60$, $0.90,1.50$ and 2.79 with $N_{\max }$ being the highest level of fertiliser $\mathrm{N}$ applied in $\mathrm{kg} / \mathrm{ha}$. Thus, the exponential coefficient could assume several values to get flexibility of the curves. The $c$ value, which yielded the 
lowest residual sum of squares, defines the curve of best fit. As above-mentioned, the critical sidedress $\mathrm{N}$ rates were obtained solving these equations for $95 \%$ of maximum tuber yield. Considering the continuous increase of this type of curves, maximum tuber yield is the point corresponding to the higher sidedress $\mathrm{N}$ rate applied. However, when $300 \mathrm{~kg} \mathrm{~N} / \mathrm{ha}$ were applied at preplant, as well as $200 \mathrm{~kg} \mathrm{~N} / \mathrm{ha}$ in 1997 and 1998, the effect on tuber yield of sidedress $\mathrm{N}$ was not evident. In 1997, when 200 and $300 \mathrm{~kg} \mathrm{~N} / \mathrm{ha}$ were applied at preplant, the exponential curves showed the concavity turned upwards. In 1996 with $300 \mathrm{~kg} \mathrm{~N} / \mathrm{ha}$ and in 1998 with $200 \mathrm{~kg} \mathrm{~N} / \mathrm{ha}$, the curves showed a continuous decrease in tuber yield starting at the control treatment. In 1998 , when $300 \mathrm{~kg} \mathrm{~N} / \mathrm{ha}$ were applied at preplant, the slight increase observed in tuber yield with sidedress $\mathrm{N}$ was less than $5 \%$ of maximum tuber yield. Thus, in all these five situations, we considered the critical sidedress $\mathrm{N}$ rate as $0 \mathrm{~kg} \mathrm{~N} / \mathrm{ha}$.

In a second step, multiple regression equations were proposed to obtain quantitative sidedress $\mathrm{N}$ rates as a function of crop $\mathrm{N}$ nutritional indices and days after emergence. The multiple regression equations were established in the form of:

$z=a+b y+c x$

where $z$ is recommended sidedress $\mathrm{N}$ rate, $y$ is a given nitrogen nutritional index, $x$ is days after crop emergence and $a, b$ and $c$ are coefficients determined from experimental data. The equations take into account the decreasing linear relationship observed between the $\mathrm{N}$ nutritional indices and the critical sidedress $\mathrm{N}$ rates as calculated in the first step. They also consider the linear decrease on the petiole nitrate concentration and leaf $\mathrm{N}$ throughout the growing season, observed between 10 and 48 days after emergence, independently of the preplant treatment.

\section{Results}

The tuber yield responses to the $\mathrm{N}$ applied at preplant and sidedress are shown in Fig. 1. The yield responses to preplant $\mathrm{N}$ were plotted on the $y$ lines on each of the individual small figures, corresponding to the plots where no $\mathrm{N}$ was applied as sidedress. The Fig. 1 also includes the fitting curves corresponding to the exponential asymptotic model and their equa- tions represent the tuber yield responses to sidedress $\mathrm{N}$ rate. Minimum tuber yields were recorded on control treatments, where $\mathrm{N}$ was neither applied at preplant nor sidedress (Fig. 1, Pp0). Tuber yields recorded on control plots were 42.8, 23.5 and 32.3 Mg/ha in 1996, 1997 and 1998, respectively. As higher the $\mathrm{N}$ rate applied at preplant, the lower the tuber yield response to sidedress $\mathrm{N}$ and vice versa. Maximum tuber yields close to $50 \mathrm{Mg} / \mathrm{ha}$, resulting from diverse combinations of preplant and sidedress $\mathrm{N}$ rates, were recorded for all the years. Thus, this value could define the yield potential of the agro-system.

The estimated critical sidedress $\mathrm{N}$ rates ranged from 0 to $149 \mathrm{~kg} \mathrm{~N} / \mathrm{ha}$ (Table 1 ). Nought and lower values were found on plots where high amounts of $\mathrm{N}$ were applied at preplant. The preplant treatments, which do not provide enough $\mathrm{N}$ for adequate crop growth, such as control, $50 \mathrm{~kg}$ urea-N/ha and the treatments consisting on organic amendments as nitrogen source, lead to higher values of critical sidedress $\mathrm{N}$ rates.

Quantified sidedress $\mathrm{N}$ rates as a function of petiole nitrate concentrations and sampling dates are given by the multiple regression equation presented in Fig. 2. The negative partial regression coefficient $(-4.15)$ for the PNLab variable, indicates lower recommended sidedress $\mathrm{N}$ rates as higher petiole nitrate concentration is for a given sampling date. For a given value of petiole nitrate concentration, the recommended sidedress $\mathrm{N}$ rate decreases as the growing season progresses, since the partial regression coefficient for DAE is also negative $(-1.87)$. The potential and the functioning of the

Table 1

Critical sidedress $\mathrm{N}$ rates estimated from tuber yield response to nitrogen applied as sidedress over each preplant treatment of the 3 years of study

\begin{tabular}{lccc}
\hline $\begin{array}{l}\text { Preplant treatments }(\mathrm{kg} \\
\text { N/ha) }\end{array}$ & \multicolumn{3}{c}{ Critical sidedress N rates (kg/ha) } \\
\cline { 2 - 4 } & 1996 & 1997 & 1998 \\
\hline 0 (control) & 92 & 149 & 80 \\
50 (urea) & 62 & 120 & 73 \\
100 (urea) & 58 & 95 & 32 \\
200 (urea) & 24 & 0 & 0 \\
300 (urea) & 0 & 0 & 0 \\
100 (poultry manure) & 37 & 136 & 121 \\
100 (farmyard manure) & 121 & 144 & 69 \\
100 (mun. sol. waste) & 68 & 138 & 89 \\
\hline
\end{tabular}

The values were obtained solving the equations of Fig. 1 for $95 \%$ of maximum tuber yield. 
- $1996 \bullet 1997$ o 1998
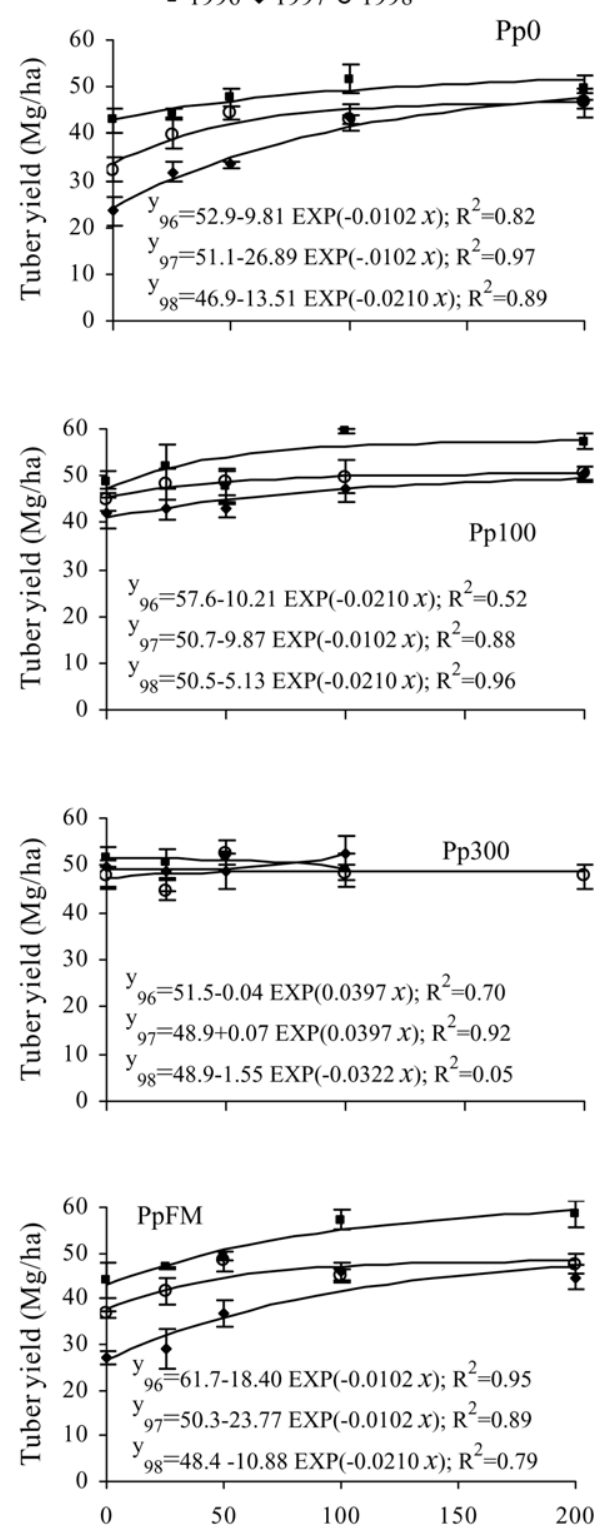

Applied sidedress $\mathrm{N}(\mathrm{kg} / \mathrm{ha})$
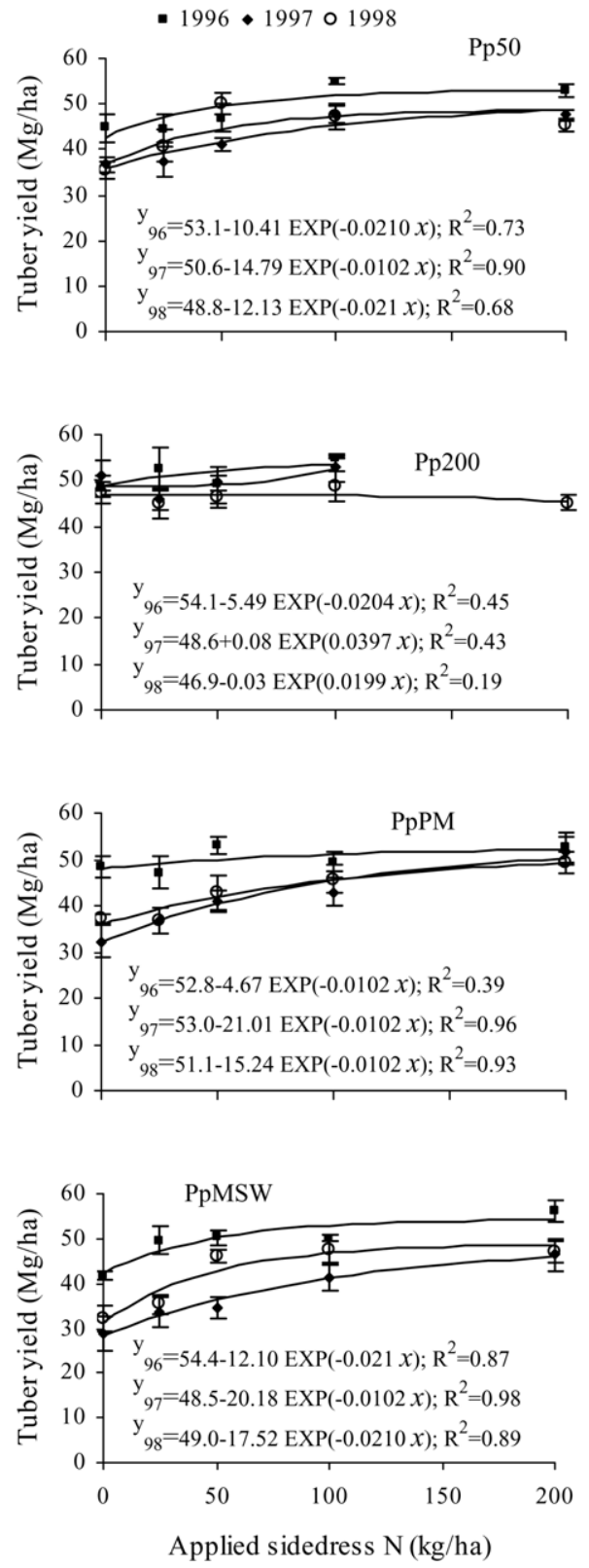

Fig. 1. Relationships between applied sidedress N $(x)$ and tuber yield (in 1996, $y_{96} ; 1997, y_{97} ; 1998, y_{98}$ ). Pp0, Pp50, Pp100, Pp200, Pp300, PpPM, PpFM and PpMSW are the preplant treatments, which consisted on 0, 50, 100, 200 and $300 \mathrm{~kg}$ urea-N/ha and $100 \mathrm{~kg}$ organic-N/ha as poultry manure, farmyard manure and municipal solid waste, respectively. Vertical bars are standard deviations of the means.

equation could be fully understood following this example: if at 20 days after emergence, the petiole nitrate$\mathrm{N}$ concentrations is $30 \mathrm{~g} \mathrm{~kg}^{-1}$, the recommended sidedress $\mathrm{N}$ dose is $21 \mathrm{~kg} / \mathrm{ha}$; if at the same sampling date, the petiole nitrate- $\mathrm{N}$ concentration is only $10 \mathrm{~g} \mathrm{~kg}^{-1}$, the estimated sidedress $\mathrm{N}$ dose is $104 \mathrm{~kg} / \mathrm{ha}$, and if the petiole nitrate- $\mathrm{N}$ concentration is $10 \mathrm{~g} \mathrm{~kg}^{-1}$ at $45 \mathrm{DAE}$, the sidedress $\mathrm{N}$ required is $57 \mathrm{~kg} / \mathrm{ha}$. 


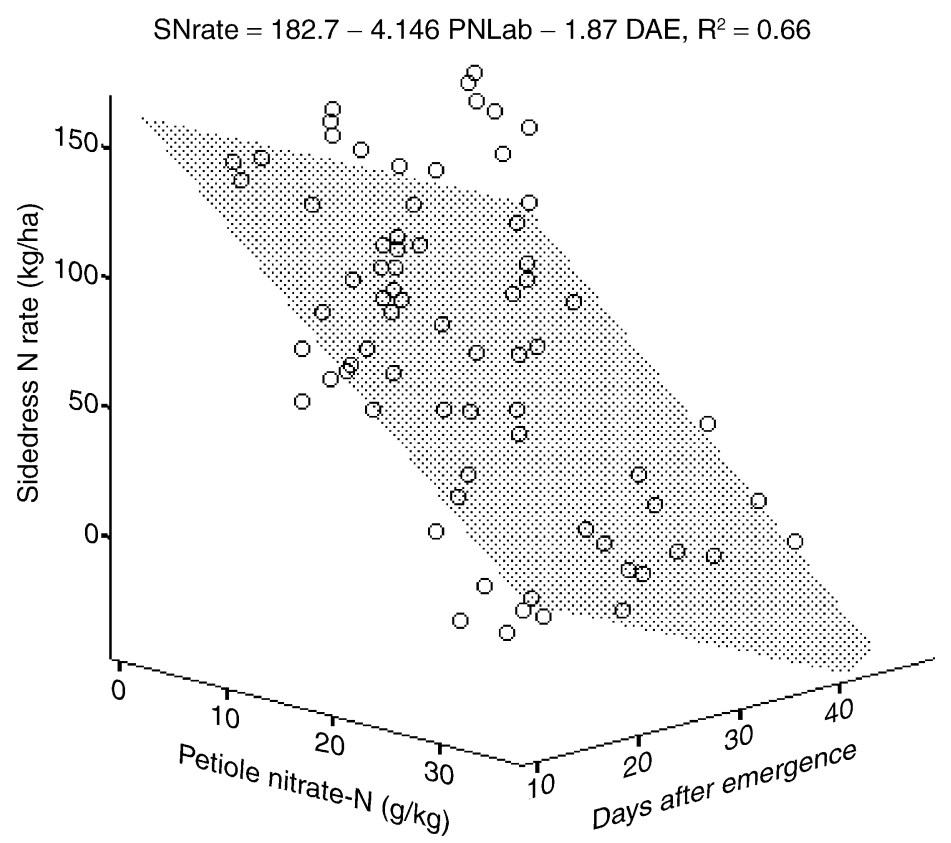

Fig. 2. Plane and respective equation, which provide the recommended sidedress $\mathrm{N}$ rate (SNrate) as a function of petiole nitrate-N concentration (PNLab, dry weight basis) and days after crop emergence (DAE).

Quantified sidedress $\mathrm{N}$ rates as a function of petiole nitrate concentrations (performed in fresh tissues with the RQflex reflectometer) and days after emergence can be obtained from the regression equation shown in Fig. 3. The pattern of the response surface is similar to that of Fig. 2, notwithstanding the fact that the partial regression coefficient for PNRQflex $(-0.013)$ is much different due to the units in which the results are expressed.

Taking into consideration the simplicity of the portable tool, its accuracy was double checked using standard $\mathrm{Ca}\left(\mathrm{NO}_{3}\right)_{2}$ solutions and their results compared with the laboratorial analysis. We stress that RQflex readings and laboratory analysis were performed on random sub-samples of the same petiole sample. The relationship between nitrate concentrations in $\mathrm{Ca}\left(\mathrm{NO}_{3}\right)_{2}$ solutions and RQflex readings is shown in Fig. 4. The relationship between petiole nitrate concentrations determined from laboratory analysis and with the RQflex reflectometer is shown in Fig. 5. The slope of the linear regression between nitrate concentrations in $\mathrm{Ca}\left(\mathrm{NO}_{3}\right)_{2}$ solutions and RQflex readings is 1.03 (Fig. 4). Testing the hypotheses $H_{0}$ : $\beta_{1}=1$ versus $H_{\mathrm{a}}: \beta_{1} \neq 1$, the null hypothesis was not rejected $(p<0.01)$, meaning that $\mathrm{RQflex}$ readings do not need calibration in the reactivity range of reflectoquant test strips. It was also attained a close correlation $(r=0.96)$ between petiole nitrate concentrations determined by the laboratory method and RQflex reflectometer (Fig. 5), even considering the dissimilar process of extracts preparation. For laboratory analysis, we used dried and ground petioles, whilst the extracts were prepared from fresh tissues for RQflex readings.

The multiple regression equation providing the recommended sidedress $\mathrm{N}$ rates as a function of leaf $\mathrm{N}$ and DAE is shown in Fig. 6. The multiple coefficient of determination $\left(R^{2}=0.59\right)$ is not much different to that obtained with the petiole nitrate concentration, despite the latter being the most common $\mathrm{N}$ nutritional status index in potato crop. As with petiole nitrate concentration, as higher the leaf $\mathrm{N}$ content is, the lower is the recommended sidedress $\mathrm{N}$ rate for a given sampling date. For similar levels of leaf $\mathrm{N}$ content, the recommended sidedress $\mathrm{N}$ rates also decreases with time.

Fig. 7 shows the scatter diagram of the multiple regression equations residues. The deviation of observed to estimated values by regression surface ranged from -57 to $+67,-61$ to +54 and -56 to $+59 \mathrm{~kg} \mathrm{~N} / \mathrm{ha}$, re- 


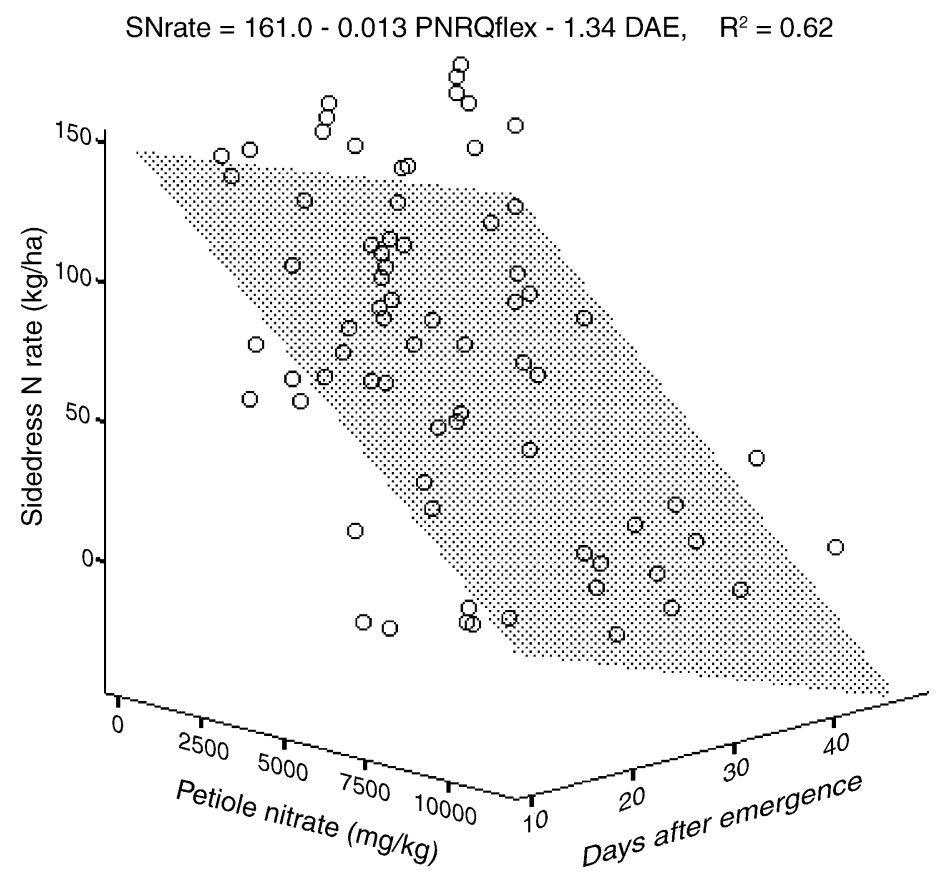

Fig. 3. Plane and respective equation, which provide the recommended sidedress $\mathrm{N}$ rate (SNrate) as a function of petiole nitrate concentration (PNRQflex, fresh weight basis) and days after crop emergence (DAE).

spectively for PNLab, PNRQflex and LeafN. The dots were plotted by sampling date to allow for a follow up of their evolution during the growing season. We could observe some variation between sampling dates of the different years. However, the pattern of residues distribution throughout the season seems to support the model application between 10 and 48 days after crop emergence.

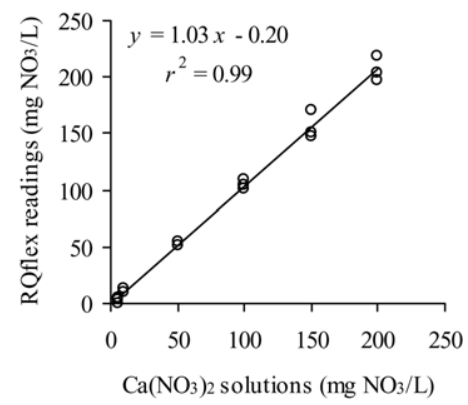

Fig. 4. Relationship between nitrate concentrations in extracts prepared from $\mathrm{Ca}\left(\mathrm{NO}_{3}\right)_{2}$ and $\mathrm{RQflex}$ readings.

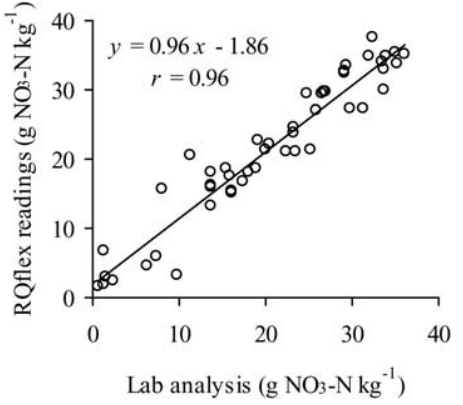

Fig. 5. Relationship between petiole nitrate concentrations determined by a standard laboratorial procedure and with the RQflex reflectometer. Extracts were prepared from random sub-samples of the same petiole sample.

\section{Discussion}

The exponential asymptotic model fitted very well to the data in the range of sidedress $\mathrm{N}$ rates used, because there were no evident decreases in tuber yields for the higher $\mathrm{N}$ rates. It is common in potato crop the development of an ample plateau where tuber yield 


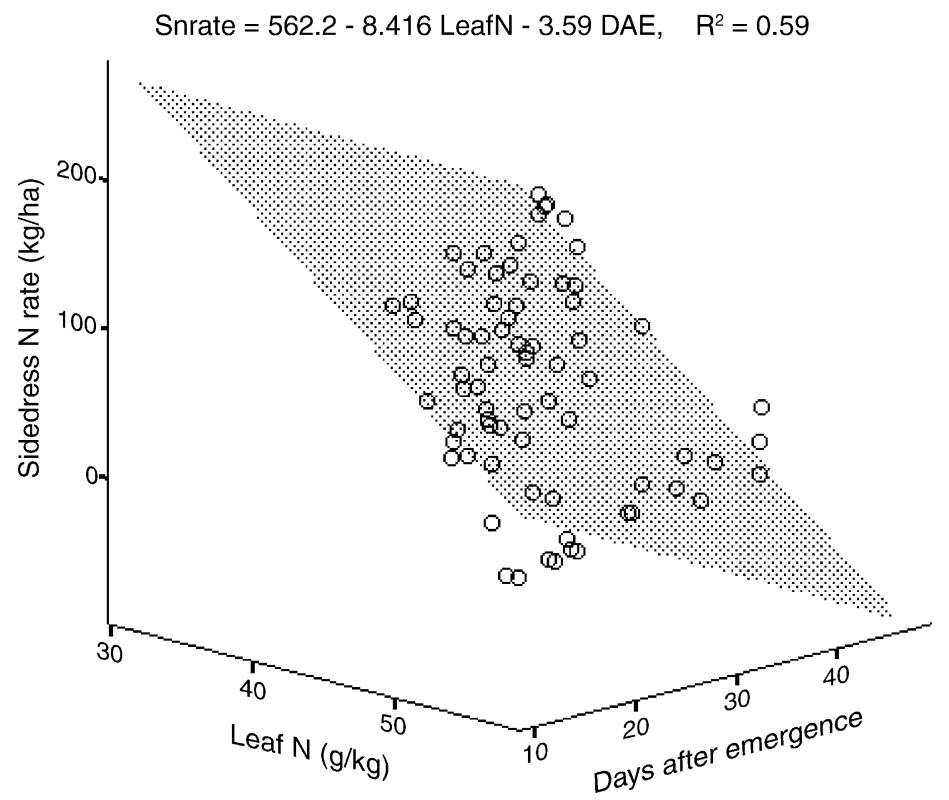

Fig. 6. Plane and respective equation, which provide the recommended sidedress $\mathrm{N}$ rate (SNrate) as a function of leaf $\mathrm{N}$ (LeafN) and days after crop emergence (DAE).

does not decrease, even when excessive $\mathrm{N}$ rates are used (Harris, 1992). This phenomenon was previously reported by Rodrigues et al. (2001) from studies carried out in the same agro-system, using $\mathrm{N}$ rates in the range of 0 and $500 \mathrm{~kg} \mathrm{~N} / \mathrm{ha}$. Thus, the exponential asymptotic model also seems to agree with a biological results' interpretation.

Tuber yield was dependent to preplant and sidedress $\mathrm{N}$ rate and to the year. The effect of applied $\mathrm{N}$ on tuber yield is well documented and has been reported worldwide. The yearly differences found on tuber yield, mainly in control plots, could be justified by differences in $\mathrm{N}$ availability from soil reserves. An in situ incubation technique, carried out in the context of this study, showed significant differences in soil inorganic $\mathrm{N}$ released during the growing season (Rodrigues, 2004). Neeteson and Wadman (1987) reported a clarifying result on this topic. Using data of 99 field experiments scattered over the Netherlands, the authors found economically optimum $\mathrm{N}$ rates ranging between 0 and $400 \mathrm{~kg} / \mathrm{ha}$. Differences in soil $\mathrm{N}$ availability were considered as the main factor influencing the results. As expected, the estimated critical sidedress $\mathrm{N}$ rates were higher, as lower the preplant $\mathrm{N}$ rates and vice versa. Thus, crop response to sidedress $\mathrm{N}$ rate de- pends on $\mathrm{N}$ release from soil reserves and $\mathrm{N}$ applied at preplant.

Singh (1993) reported optimal sidedress N rates decreasing as higher the petiole nitrate- $\mathrm{N}$ concentrations. From petiolar $\mathrm{NO}_{3}-\mathrm{N}$ concentrations of $0.5,1.0,1.5$, 2.0 and $2.5 \%$ at 30 days after planting, Singh (1993) obtained the corresponding optimal rates of sidedress $\mathrm{N}$ of 142, 116, 90, 64 and $37 \mathrm{~kg} / \mathrm{ha}$ for cv. Kufri Chandramukhi and 183, 164, 146, 127 and $108 \mathrm{~kg} / \mathrm{ha}$ for $\mathrm{cv}$. Kufri Badshah. If the multiple regression equation of the Fig. 2 is running with the above petiolar $\mathrm{NO}_{3}-\mathrm{N}$ values and considering 30 days after planting similar to 15 days after emergence, the sidedress $\mathrm{N}$ rates recommended are 134, 113, 93, 72 and $51 \mathrm{~kg} / \mathrm{ha}$. Singh (1993) and our results could not be considered much dissimilar, notwithstanding the differences in experimental conditions in India and Portugal and also the cultivars.

There is abundant literature reporting critical levels for petiole nitrate concentration in potatoes. The critical level represents the crop nutritional status, above which the probability of crop response to more $\mathrm{N}$ is low. Thus, if the equation is solved using critical petiole nitrate concentrations, the sidedress $\mathrm{N}$ rate recommended would be close to $0 \mathrm{~kg} / \mathrm{ha}$. Westcott et al. 

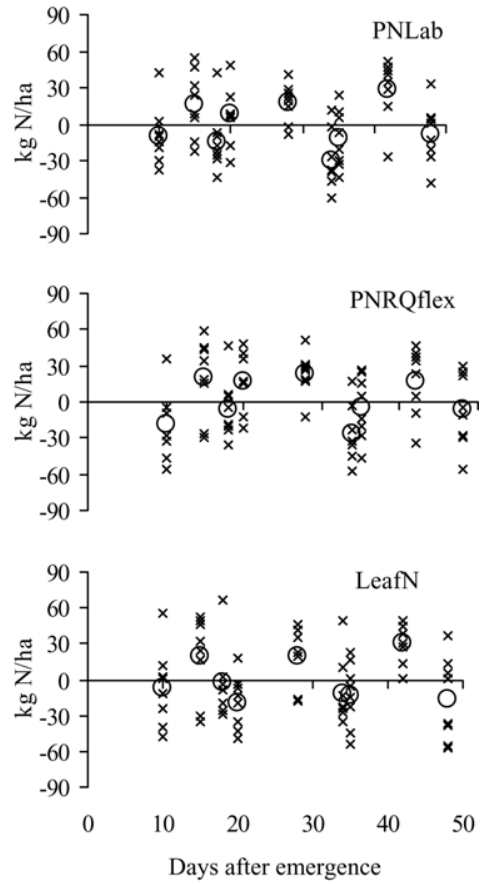

Fig. 7. Residues of recommended sidedress $\mathrm{N}$ rates obtained as the difference between observed and estimated values from the equations of Figs. 2, 3 and 6. PNLab, data of petiole nitrate concentration (dry weight basis); PNRQflex, petiole nitrate concentration (fresh weight basis); LeafN, leaf $\mathrm{N}$ concentration. Each vertical line of dots represents the residues of the different sampling dates. The open rings represent the mean values of residues of each sampling date.

(1991) reported critical petiole nitrate levels in potato (cv. Russet Burbank) of $25 \mathrm{~g} \mathrm{~kg}^{-1}$ at tuber initiation (TI), $14 \mathrm{~g} \mathrm{~kg}^{-1}$ at $\mathrm{TI}+21$ days and $10 \mathrm{~g} \mathrm{~kg}^{-1}$ at $\mathrm{TI}+42$ days. Considering TI equivalent to our time scale of 20 DAE, the equation of the Fig. 2 gives sidedress $\mathrm{N}$ rates of 42,48 and $25 \mathrm{~kg} / \mathrm{ha}$, respectively. If the equation is solved with other published critical levels (e.g. Porter and Sisson, 1991; Singh, 1993; Bélanger et al., 2003), estimated sidedress $\mathrm{N}$ rates are always slightly higher than zero. This apparent overestimation of $\mathrm{N}$ rate above $0 \mathrm{~kg} / \mathrm{ha}$ could be justified, taking into account the manner in which critical levels are determined. The critical levels reported in literature were determined by different ways: fitting the curves between petiole nitrate concentrations and tuber yields (Gupta and Saxena, 1976; Singh, 1993), including the linear plateau model (Westcott et al., 1991); or using the graphical Cate-Nelson procedure (Evanylo, 1989; Porter and Sisson, 1991). In the first case, the critical levels are obtained solving the equations for 90 or $95 \%$ of maximum yield, which implies an important yield reduction. If the graphical Cate-Nelson procedure is used, a variable, but often higher, yield reduction is implicit. Taken into account that in this work, the critical sidedress $\mathrm{N}$ rates were estimated assuming only $5 \%$ of yield reduction, these results concur with critical levels reported worldwide.

The RQflex reflectometer yielded accurate readings on extracts prepared from $\mathrm{Ca}\left(\mathrm{NO}_{3}\right)_{2}$ and from petiole samples, taking into account how simple and inexpensive the tool is. Many surveys, using quick tools with apparent success, have been carried out to monitor the N nutritional status of several crops (Schaefer, 1986; Jeminson and Fox, 1988; Nitsch and Varis, 1991; Westcott et al., 1993; Sims et al., 1995). However, we are unaware of any work using this specific equipment, but from these results, it seems to show a high usefulness potential. The farmers and field consultants need simple equipments, like RQflex reflectometer, to diagnose the $\mathrm{N}$ nutritional status of annual crops. The growth rate of annual crops is high and laboratories often take too much time to provide a diagnostic. So, if the nutritional status of a crop approaches a deficiency level at the time of sampling, a high yield loss could occur when corrective measures are delayed.

Leaf $\mathrm{N}$ is not commonly used as $\mathrm{N}$ nutritional index in potatoes. The exception being situations where a multi-elemental analysis, to monitor the accuracy of a fertilizer recommendation program, is desired. The petiole nitrate concentration is most widespread when the purpose is the early diagnostic of a $\mathrm{N}$ deficiency, to allow for in-season adjustments of $\mathrm{N}$ doses. However, leaf $\mathrm{N}$ can also be used as $\mathrm{N}$ nutritional index. Evanylo (1989) reported critical leaf $\mathrm{N}$ with cv. Superior of $58 \mathrm{~g} \mathrm{~kg}^{-1}$ at 14 days after emergence and $51.6 \mathrm{~g} \mathrm{~kg}^{-1}$ at midbloom ( $\left.\approx 35 \mathrm{DAE}\right)$. Using such values to solve Fig. 6 equation, one obtains 24 and $2 \mathrm{~kg} / \mathrm{ha}$, respectively, as recommended sidedress $\mathrm{N}$ rates. These values are very close to zero, the theoretically expected result and show agreement between the methodologies reported in this work and the classical approach by critical levels.

The strategy proposed in this work consists on transferring of at least part of the decision of $\mathrm{N}$ quantification from preplant to sidedress time. It assumes the difficulties on $\mathrm{N}$ rate quantification before the start of 
the growing season found worldwide in many $\mathrm{N}$ recommendation programs. We suggest the application of moderate $\mathrm{N}$ rates at preplant with final corrections of $\mathrm{N}$ fertilisation at sidedress, based upon $\mathrm{N}$ nutritional indices. The plots of residues (Fig. 7) show that we could use the equations of Figs. 2, 3 and 6 between 10 and 48 days after crop emergence. This period covers the most adequate part of growing season to correct a nitrogen shortage. Delaying fertiliser-N application may reduce the $\mathrm{N}$ use efficiency.

\section{Acknowledgements}

The authors thank Rita Diz and Ana Pinto for laboratory assistance, Sergio Deusdado for helping on statistical software and Chrys Chrystello for English improvement. Financial support was provided by the Ministry of Agriculture, Rural Development and Fisheries through the Project PAMAF 6107, and FCT through the Project PRAXIS P/AGR/11045/98.

\section{References}

Baethgen, W.E., Alley, M.M., 1989. Optimizing soil and fertilizer nitrogen use by intensively managed winter wheat II. Critical levels and optimum rates of nitrogen fertilizer. Agron. J. 81, 120-125.

Bélanger, G., Walsh, R., Richards, J.E., Milburn, P.H., Ziadi, N., 2003. Critical petiole nitrate concentration of two processing cultivars in Eastern Canada. Am. J. Potato Res. 80, 252-262.

Dahnke, W.C., Johnson, G.V., 1990. Testing soils for available nitrogen. In: Westerman, R.L. (Ed.), Soil Testing and Plant Analysi, third ed. SSSA, Book Series 3, pp. 127-139.

Doorenbos, J., Pruit, W.O. 1977. Guidelines for Predicting Crop Water Requirements. FAO Irrigation and Drainage Paper 24, Rome.

Evanylo, G.K., 1989. Rate and timing of nitrogen fertilizer for white potatoes in Virginia. Am. Potato J. 66, 461-470.

Gupta, A., Saxena, M.C., 1976. Evaluation of leaf analysis as a guide to nitrogen and phosphorus fertilization of potato (Solanum tuberosum L.). Plant Soil 44, 597-605.

Harris, P.M., 1992. Mineral nutrition. In: Harris, P.M. (Ed.), The Potato Crop: The Scientific Basis for Improvement, second ed. Chapman \& Hall, London, pp. 163-213.

Heckman, J., Govindasamy, R., Prostak, D.J., Chamberlain, E.A., Hlubit, W.T., Mickel, R.C., Prostko, E.P., 1996. Corn response to sidedress nitrogen in relation to soil nitrate concentration. Commun. Soil Sci. Plant Anal. 27 (3 and 4), 575-583.

Houba, V.J., van der Lee, J.J., Novozamsky, I., Walinga, I., 1989. Soil and plant analysis. In: Part 5. Soil Analysis Procedure. Wageningen Agricultural University, The Netherlands.

Jeminson, J.M., Fox, R.H., 1988. A quick-test procedure for soil and plant tissue nitrates using test strips and a hand-held reflectometer. Commun. Soil Sci. Plant Anal. 19 (4), 1569-1582.

Lemaire, G., Gastal, F., 1997. N uptake and distribution in plant canopies. In: Lemaire, G. (Ed.), Diagnosis of the Nitrogen Status in Crops. Springer-Verlag, Heidelberg, pp. 3-44.

Neeteson, J.J., Wadman, W.P., 1987. Assessment of economically optimum application rates of fertilizer $\mathrm{N}$ on the basis of response curves. Fertil. Res. 12, 37-52.

Nitsch, A., Varis, E., 1991. Nitrate estimates using the Nitrachek test for precise $\mathrm{N}$-fertilization during plant growth and after harvest, for quality testing potato tubers. Potato Res. 34, 95-105.

Ojala, J.C., Strark, J.C., Kleinkopf, G.E., 1990. Influence of irrigation and nitrogen management on potato yield and quality. Am. Potato J. 67, 29-43.

Piekielek, W.P., Fox, R.H., Coth, J.D., Macneal, K.E., 1995. Use a chlorophyll meter at the early dent stage of corn to evaluate nitrogen sufficiency. Agron. J. 87, 403-408.

Porter, G.A., Sisson, J.A., 1991. Petiole nitrate content of mainegrown Russet Burbank and Shepody potatoes in response to varying nitrogen rate. Am. Potato J. 68, 493-505.

Rodrigues, M.A., 2004. An in situ incubation technique to measure the contribution of organic $\mathrm{N}$ to potatoes. Agronomie 24, 249-256.

Rodrigues, M.A., Coutinho, J., Martins, F., Soutinho, J.C., 2001. Fertilização azotada da batateira. Produtividade e aspectos qualitativos da cv. Désireé. Revista de Ciências Agrárias XXIV (3 and 4), 184-192.

Schaefer, N.L., 1986. Evaluation of a hand reflectometer for rapid quantitative determination of nitrate. Commun. Soil Sci. Plant Anal. 17 (9), 937-951.

Scharf, P.C., 2001. Soil and plant tests to predict optimum nitrogen rates for corn. J. Plant Nutr. 24 (6), 805-826.

Sims, J.T., Basilas, B.L., Gartley, K.L., Milliken, B., Green, V., 1995. Evaluation of soil and plant nitrogen test for maize and manured soils of the atlantic coastal plain. Agron. J. 87, 213-222.

Singh, J.P., 1993. Tissue analysis technology for nitrate fertilization of potato grown under subtropics short day conditions. Fertil. Res. 36, 19-27.

Westcott, M.P., Rosen, C.J., Inskeep, W.P., 1993. Direct measurements of petiole sap nitrate in potato to determine crop nitrogen status. J. Plant Nutr. 16 (3), 515-521.

Westcott, M.P., Stewart, V.R., Lund, R.E., 1991. Critical petiole nitrate levels in potato. Agron. J. 83, 844-850.

Westermann, D.T., Kleinkopf, G.E., Porter, L.K., 1988. Nitrogen fertiliser efficiencies on potatoes. Am. Potato J. 65, 377-386. 